\title{
A novel curcumin derivative increases the cytotoxicity of raloxifene in estrogen receptor-negative breast cancer cell lines
}

\author{
SEBASTIEN TAURIN ${ }^{1}$, MHAIRI NIMICK $^{1}$, LESLEY LARSEN $^{2}$ and RHONDA J. ROSENGREN ${ }^{1}$ \\ Departments of ${ }^{1}$ Pharmacology and Toxicology, and ${ }^{2}$ Chemistry, University of Otago, Dunedin 9054, New Zealand
}

Received August 27, 2015; Accepted October 9, 2015

DOI: $10.3892 / \mathrm{ijo} .2015 .3252$

\begin{abstract}
There is a need for new, safe and efficacious drug therapies for the treatment of estrogen receptor (ER)-negative breast cancers. Raloxifene and the 2 nd generation curcumin derivative 2,6-bis(pyridin-4-ylmethylene)-cyclohexanone (RL91) have been shown to inhibit the growth of ER-negative breast cancer cells in vitro and in vivo. We investigated whether RL91 could enhance the growth-suppressive effects mediated by raloxifene in MDA-MB-231, MDA-MB-468, Hs578t and $\mathrm{SkBr} 3$ human breast cancer cell lines. The cytotoxicity was consistent across the cell lines but RL91 was more potent. $\mathrm{EC}_{50}$ values for RL91 were 1.2-2 $\mu \mathrm{M}$ while $\mathrm{EC}_{50}$ values for raloxifene were 9.6-11.2 $\mu \mathrm{M}$. When the cells were treated with raloxifene $(15 \mu \mathrm{M})$, RL91 $(1 \mu \mathrm{M})$ or a combination of the two for $6-72 \mathrm{~h}$, the combination treatment consistently elicited significantly greater cytotoxicity compared to all other treatments. In $\mathrm{SkBr} 3$ cells the combination treatment caused significantly more cells to undergo G1 arrest compared to raloxifene. In all cell lines apoptosis was synergistically induced by the combination treatment, as shown by both flow cytometery and cleaved caspase-3. Furthermore, the stress kinase p38 was increased and EFGR isoforms were decreased by both raloxifene and raloxifene + RL91. The anti-angiogenic anti-metastatic potential of raloxifene was not increased by RL91, as MDA-MB-231 cell migration and invasion as well as endothelial tube formation by HUVEC cells was not different between raloxifene $(10 \mu \mathrm{M})$ and the combination of raloxifene + RL91. Thus, our findings provide evidence that RL91 increases the ability of raloxifene to suppress ER-negative cancer cell growth by increasing the number of apoptotic cells. The broad effect of this drug combination across a range of ER-negative breast cancer cell lines indicates that this drug combination should be explored further in order to find a safe and efficacious therapy for ER-negative breast cancer.
\end{abstract}

Correspondence to: Professor Rhonda J. Rosengren, Department of Pharmacology and Toxicology, University of Otago, 18 Frederick Street, Dunedin 9054, New Zealand

E-mail: rhonda.rosengren@otago.ac.nz

Key words: raloxifene, RL91, MDA-MB-231, MDA-MB-468, SkBr3, Hs578t, EGFR, HER2

\section{Introduction}

Selective estrogen receptor modulators (SERMs) such as tamoxifen and raloxifene are effective treatments for the prevention of estrogen receptor (ER)-positive breast cancer. Raloxifene, a second generation SERM, has been approved for the prevention of osteoporosis and the reduction of the risk of invasive breast cancer in post-menopausal women (1). In breast tissue, SERMs prevent the proliferation of cancer cells by binding competitively to the ER and blocking the mitogenic effect of estradiol (2). Although SERMs are used clinically as an ER antagonist, there are numerous studies showing that they exhibit effects that are not mediated via the ER. For example, SERMs have shown efficacy when used in cancers that do not express ER such as lung (3), brain cancer (4), melanoma (5) and ER-negative breast cancer (6-8). Furthermore, in vitro, SERMs trigger multiple signaling pathways that lead to cancer cell death in an ER-independent manner (9). This provides a potential role for these drugs in triple-negative breast cancers (TNBC) that lack the standard drug targets ER $\alpha$, the progesterone receptor and HER2/neu. Indeed, we have previously shown that the combination of raloxifene and epigallocatechin gallate (EGCG) was cytotoxic toward the aggressive, basal-like (ER-negative/HER2-negative) MDA-MB-231 cell line (10). Additionally, the combination of EGCG and raloxifene elicited a strong apoptotic response, which occurred independently of cell cycle changes (10) and resulted in a significant decrease in the phosphorylation of the EGFR, Akt, mTOR as well as the nuclear localization of NF- $\kappa \mathrm{B}$ compared to raloxifene alone (11). The efficacy of raloxifene was also increased when it was used in combination with 9-cis retinoic acid in a rodent model of mammary carcinogenesis induced by nitroso-methylurea (12). Therefore, combination therapy with SERMs may prove to be beneficial in the treatment of TNBC. A prime candidate for combination therapy with raloxifene would be second generation curcumin derivatives because we have previously shown that various derivatives, including 2,6-bis(pyridin-4-ylmethylene)-cyclohexanone, (RL91), 6-bis(pyridin-3-ylmethylene)-cyclohexanone (RL90), 1-methyl-3,5-bis[(E)-4-pyridyl)methylidene]-4-piperidone, (RL66) and 3,5-bis(3,4,5-trimethoxybenzylidene)-1-methylpiperidine-4-one (RL71) all decreased the phosphorylation of the EGFR, Akt and mTOR (13-15) as well as other proteins involved in the regulation of cell proliferation. Furthermore, raloxifene $(10 \mu \mathrm{M})$ decreased proliferation of MDA-MB-468 
cells through the endocytosis of the EGFR leading to a decrease in proliferation signaling pathways (8). Based on these earlier findings, we postulated that RL91 would enhance the cytotoxicity of raloxifene in ER-negative breast cancer cell lines and that this effect would be mediated through changes in EGFR signaling. In the present study, we showed that a combination of raloxifene and RL91 promoted cell cycle arrest in G1 phase of the cell cycle and increased the incidence of apoptosis across all the ER-negative breast cancer cell lines. Furthermore, the combination altered the expression of proteins essential for cell proliferation and apoptosis. Finally, we demonstrated that the combination reduced cell migration and invasion and completely abolished tube-like formation of endothelial cells.

\section{Materials and methods}

Materials. HUVEC, MDA-MB-231, MDA-MB-468, Hs578t and SKBr3 cells were purchased from the American Type Culture Collection (ATCC; Manassas, VA, USA). Primary antibodies to EGFR, pEGFR, GSK $3 \alpha / \beta$, pGSK $3 \alpha / \beta$, p38, pp38, NF-кB, $\beta$-catenin, cleaved caspase-3, p27Kip1, HER2, pHER2, AKT, pAKT and $\beta$-actin were purchased from Cell Signaling Technology (Danvers, MA, USA). Raloxifene hydrochloride (99\% purity), acrylamide, bisacrylamide, sodium dodecylsulfate, sulforhodamine B salt and propidium iodide (PI) were purchased from Sigma-Aldrich (Auckland, New Zealand). Secondary antibodies goat anti-rabbit and goat anti-mouse and PVDF membrane were purchased from Merck Millipore (Auckland, New Zealand). Dulbecco's modified Eagle's medium (DMEM) nutrient mixture Ham's F-12 was purchased from Thermo Fisher Scientific (Auckland, New Zealand). Complete mini EDTA-free protease inhibitor cocktail and Annexin V-Fluos were purchased from Roche Diagnostics Corp. (Auckland, New Zealand). RL91 was prepared as previously described (13). All other chemicals were of the highest purity commercially available.

Cell culture. MDA-MB-231, MDA-MB-468, Hs578t and $\mathrm{SkBr} 3$ breast cancer cells were obtained from the American Type Culture Collection. The cells were grown in complete growth media composed of DMEM/Ham's F12 supplemented with $5 \%$ fetal bovine serum (FBS), $2 \mathrm{mM}$ L-glutamine, $100 \mu \mathrm{g} / \mathrm{ml}$ streptomycin, $100 \mathrm{U} / \mathrm{ml}$ penicillin and $2.2 \mathrm{~g} / \mathrm{l}$ $\mathrm{NaHCO}_{3}$. HUVEC were seeded in complete HUVEC media (EBM-2 basal media containing FBS and growth supplements) as described by the manufacturer (Lonza, Auckland, New Zealand). For all procedures, cells were harvested using TrypLE Express (Life Technologies, Auckland, New Zealand) and were maintained at $37^{\circ} \mathrm{C}$ in a humidified atmosphere of $5 \% \mathrm{CO}_{2}$.

Cytotoxicity. ER-negative breast cancer cells were seeded in 96 well plates and incubated for $24 \mathrm{~h}$ at $37^{\circ} \mathrm{C}$ in $5 \% \mathrm{CO}_{2}$ and then treated with $0-30 \mu \mathrm{M}$ of raloxifene or RL91. DMSO $(0.1 \%)$ served as the vehicle control. The cells were incubated for $72 \mathrm{~h}$ and were fixed using trichloroacetic acid (TCA) 10\% solution. Cell number was determined using the sulforhodamine B (SRB) assay (16). The concentration required to decrease cell number by $50 \%\left(\mathrm{EC}_{50}\right)$ was determined by non-linear regres- sion using Prism software. For the time-course analysis, cells were treated with RL91 $(1 \mu \mathrm{M})$, raloxifene $(15 \mu \mathrm{M})$, a combination of the two or vehicle control for 6-72 $\mathrm{h}$. Cell number was then determined by the SRB assay. For all experiments three independent experiments were performed in triplicate. Results are expressed as cell number.

Cell cycle analysis. ER-negative breast cancer cells were seeded in 6-well culture plates in $1.5 \mathrm{ml}$ of complete growth media. Cells were treated with RL91 $(1 \mu \mathrm{M})$, raloxifene $(15 \mu \mathrm{M})$, a combination of the two or DMSO $(0.1 \%)$ for $24-48 \mathrm{~h}$. Cell cycle distribution was assessed using propidium iodide staining, as previously described (13). Samples were analyzed using a FACScalibur flow cytometer (BD Biosciences, San Jose, CA, USA) and the proportion of cells in each of G1, S and G2/M phases were determined using the CellQuest Pro software (BD Biosciences). Three independent experiments were performed in triplicate. Results are expressed as the number of cells in each phase of the cell cycle as a percent of the total number of cells.

Apoptosis analysis. ER-negative breast cancer cells were seeded in 6-well culture plates in $1.5 \mathrm{ml}$ of complete growth media. Cells were treated with RL91 (1 $\mu \mathrm{M})$, raloxifene $(15 \mu \mathrm{M})$, a combination of the two or DMSO $(0.1 \%)$ for 24-48 h. Apoptosis was assessed using Annexin V-Fluos/propidium iodide staining, as previously described (13). Samples were analyzed using a FACScalibur flow cytometer and the proportion of apoptotic cells was determined using CellQuest Pro software. Three independent experiments were performed in triplicate. Results are expressed as the number of apoptotic cells as a percent of the total number of cells.

Western blotting. ER-negative breast cancer cells were seeded in 12-well culture plates in $1 \mathrm{ml}$ of complete growth media and incubated with RL91 $(1 \mu \mathrm{M})$, raloxifene $(15 \mu \mathrm{M})$, a combination of the two or DMSO (0.1\%) for 24-48 h. Cells were then lysed in buffer containing $50 \mathrm{mM}$ Tris- $\mathrm{HCl}(\mathrm{pH} 8.0)$, $150 \mathrm{mM} \mathrm{NaCl}$, and $1 \%$ Triton $\mathrm{X}-100,1 \%$ SDS, $1 \mathrm{mM} \mathrm{NaF}$, $200 \mu \mathrm{M}$ sodium orthovanadate and protease inhibitors (1 $\mu \mathrm{g} / \mathrm{ml}$ leupeptin, $1 \mu \mathrm{g} / \mathrm{ml}$ aprotinin and $1 \mathrm{mM}$ PMSF). The lysates were cleared from insoluble material by centrifugation at 20,000 x g for $10 \mathrm{~min}$ and boiled in Laemmli buffer. Cell lysates were resolved by SDS-PAGE (40 $\mu \mathrm{g}$ protein/well) and then transferred to a PVDF membrane. Protein levels were analyzed with the indicated primary antibodies, followed by horseradish peroxidase-conjugated secondary antibodies (Merk Millipore). The film was scanned by GS-710 densitometer (Bio-Rad Laboratories). Three independent experiments were performed in triplicate. The resulting protein density is expressed as a percentage of the $\beta$-actin loading control.

Invasion assay. MDA-MB-231 cells $\left(5 \times 10^{5}\right.$ cells $\left./ \mathrm{ml}\right)$ were seeded onto growth factor-reduced Matrigel invasion chambers ( $8-\mu \mathrm{m}$ pore; BD Biosciences) and treated with raloxifene $(10 \mu \mathrm{M})$, RL91 $(1 \mu \mathrm{M})$, a combination of the two or vehicle control for $20 \mathrm{~h}$. Lower chambers contained DMEM/Ham's F12 supplemented with 5\% FBS, as a chemoattractant. Filters were fixed in methanol and stained using Diff-Quick staining solutions. Cells were counted in four fields of each well under 
Table I. $\mathrm{EC}_{50}$ values for raloxifene and RL91 in ER- breast cancer cell lines.

\begin{tabular}{|c|c|c|c|}
\hline \multirow[b]{2}{*}{ Cell line } & \multirow[b]{2}{*}{ Receptor status } & \multicolumn{2}{|c|}{$\mathrm{EC}_{50}(\mu \mathrm{M})$} \\
\hline & & Raloxifene & RL91 \\
\hline MDA-MB-231 & $\mathrm{ER}^{-}, \mathrm{PR}^{\prime}, \mathrm{HER}^{-}$ & 11 & 1.9 \\
\hline MDA-MB-468 & $\mathrm{ER}^{-}, \mathrm{PR}^{-}, \mathrm{HER} 2^{-}$ & 11.2 & 1.9 \\
\hline Hs578t & ER-, PR', HER2- & 11 & 2 \\
\hline $\mathrm{SkBr} 3$ & $\mathrm{ER}^{-}, \mathrm{PR}^{-}, \mathrm{HER}^{+}{ }^{+}$ & 10.6 & 1.2 \\
\hline
\end{tabular}

an inverted microscope at $\mathrm{x} 20$ magnification by an examiner blinded to the treatment groups. Their migration towards FBS was calculated as a percentage of control.

Endothelial tube formation assay. Tube formation was carried out using HUVEC cells. Briefly, Geltrex (Invitrogen, Auckland, New Zealand) was allowed to thaw on ice at $4^{\circ} \mathrm{C}$ overnight, then $40 \mu 1$ was pipetted into a 96-well plate and kept for $30 \mathrm{~min}$ at $37^{\circ} \mathrm{C}$ for a gel to form. HUVEC cells were seeded in triplicate on the top of Geltrex layer at a density of $1.5 \times 10^{4}$ cells/well. Raloxifene $(10 \mu \mathrm{M})$, RL91 $(1 \mu \mathrm{M})$, a combination of the two or DMSO (0.1\%) were added into the wells and incubated for $20 \mathrm{~h}$ at $37^{\circ} \mathrm{C}$ in $5 \% \mathrm{CO}_{2}$ atmosphere. Images were taken at time zero and $20 \mathrm{~h}$ by an examiner blinded to the treatment groups. Three independent experiments were performed in triplicate.

Cell migration. Migration of MDA-MB-231 cells was measured using the in vitro cell scratch assay. Once the cells in 6-well plates had reached confluence, a scratch was made with a pipette tip followed by extensive washing with serumfree medium to remove cell debris. Raloxifene $(10 \mu \mathrm{M})$, RL91 $(1 \mu \mathrm{M})$, a combination of the two or vehicle control were then added. Cells were allowed to migrate into the scratch area for $20 \mathrm{~h}$ at $37^{\circ} \mathrm{C}$. At the indicated times, cells were photographed by an examiner blinded to the treatment groups.

Statistical analysis. When time was a factor, data was analyzed with a two-way ANOVA coupled with a Tukey's post hoc test, where $\mathrm{P}<0.05$ was required for statistical significance. When time was not a factor, data were analyzed using a one-way ANOVA coupled with a Tukey's post hoc test, where $\mathrm{P}<0.05$ was required for statistical significance.

\section{Results}

To provide a frame of reference for the potency of raloxifene and RL91 in the various ER-negative breast cancer cell lines, $\mathrm{EC}_{50}$ curves were initially produced. Both compounds showed a consistent cytotoxicity across the cell lines but RL91 was more potent. Specifically, $\mathrm{EC}_{50}$ values for RL91 ranged between 1.2 and $2 \mu \mathrm{M}$ while the values for raloxifene ranged between 9.6 and $11.2 \mu \mathrm{M}$ (Table I). To determine if a low concentration of RL91 would potentiate the effect of raloxifene, the drugs were evaluated in combination, and time-course experiments were performed in each cell line. All cell lines were treated with
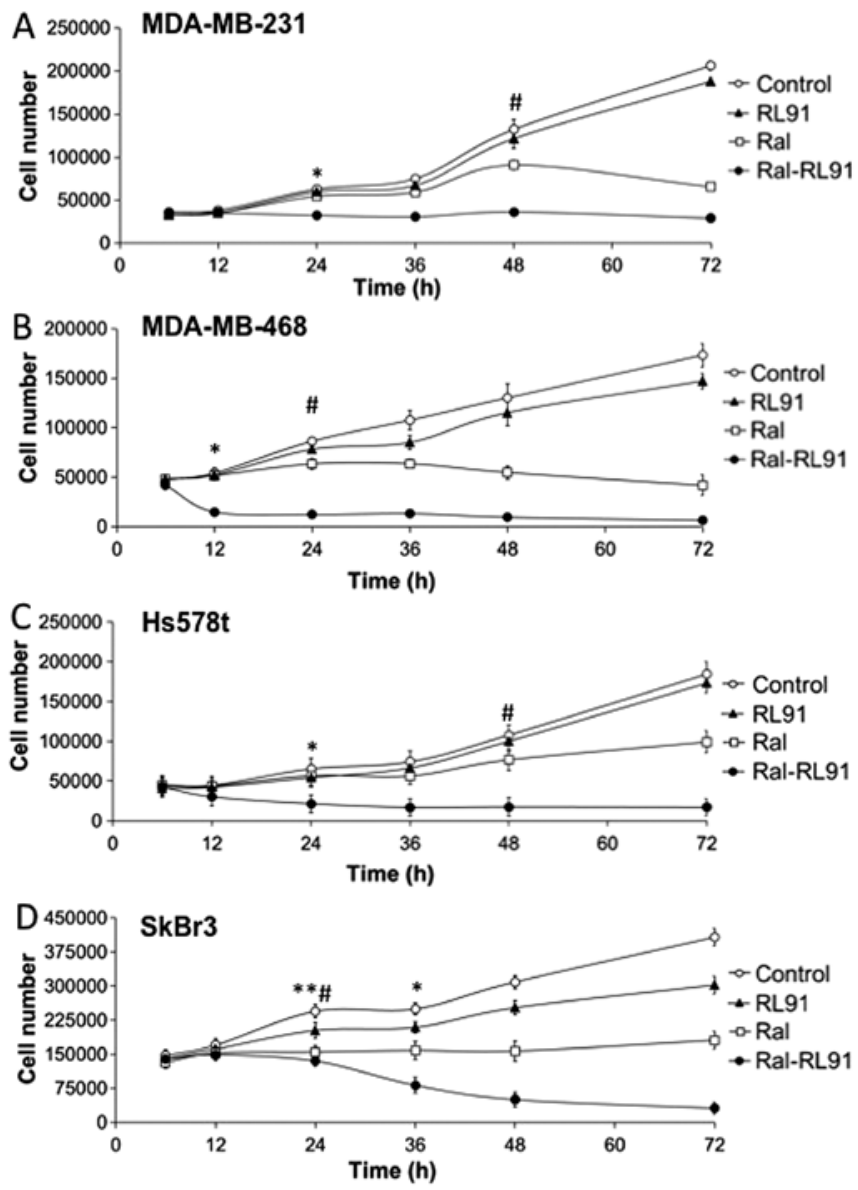

Figure 1. Raloxifene + RL91 elicits synergistic cytotoxicity towards several ER-negative breast cancer cell lines. (A) MDA-MB-231, (B) MDA-MB-468 (C) Hs578t1 and (D) $\mathrm{SkBr} 3$ cells were seeded in 24-well culture plates at $3.5 \times 10^{4}$ cells/well and were treated either with raloxifene $(15 \mu \mathrm{M})$, RL91 $(1 \mu \mathrm{M})$, the combination of the two or vehicle control (0.1\% DMSO) for 6-72 $\mathrm{h}$. At the specified time, cells were fixed and cell number was determined using the SRB assay. Results are expressed as total cell number and were obtained from three independent experiments performed in triplicate. Data were analyzed using a two-way ANOVA coupled with a Tukey's post-hoc test. ${ }^{*} \mathrm{P}<0.05$, combination treatment is significantly decreased compared to all other treatments at this point and all further time-points. ${ }^{* *} \mathrm{P}<0.05, \mathrm{RL} 91$ is significantly decreased from control at this point and all further time-points; ${ }^{\#} \mathrm{P}<0.05$, raloxifene is significantly decreased from control at this point and all further time-points.

raloxifene $(15 \mu \mathrm{M})$, RL91 $(1 \mu \mathrm{M})$ or a combination of the two for 6-72 h. SkBr3 was the only cell line to respond to RL91 $(1 \mu \mathrm{M})$, which had a growth suppressive effect. Raloxifene $(15 \mu \mathrm{M})$ significantly suppressed growth in all four cell lines and after $72 \mathrm{~h}$ was the most effective in MDA-MB-231 and MDA-MB-468 cells. The combination treatment elicited significantly greater cytotoxicity compared to all other treatments (Fig. 1). In MDA-MB-231 cells the combination treatment was cytostatic, while in the three other cell lines the combination treatment was cytotoxic.

We next determined how the combination treatment influence cell cycle progression, as raloxifene has promoted an accumulation of cells in G1 phase in MDA-MB-231 cells (10) and RL91 has elicited G2/M phase arrest (13) in numerous ER-negative breast cancer cell lines. In all cell lines raloxifene $(15 \mu \mathrm{M})$ and the combination of raloxifene and RL91 $(1 \mu \mathrm{M})$ promoted the accumulation of cells in the G1 phase of the 
A $\mathrm{Hs} 578 \mathrm{t}$
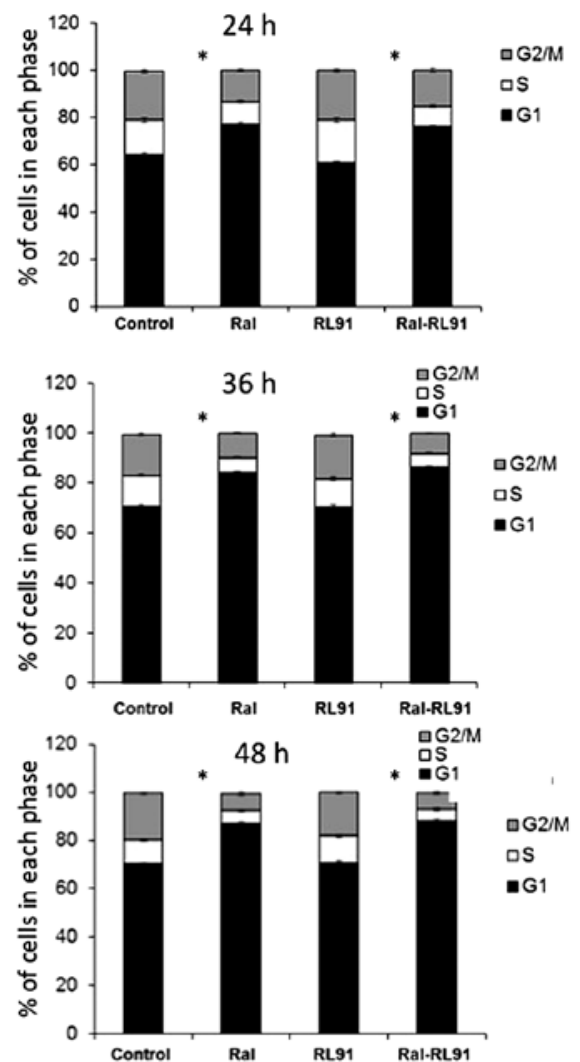

C MDA-MB-231
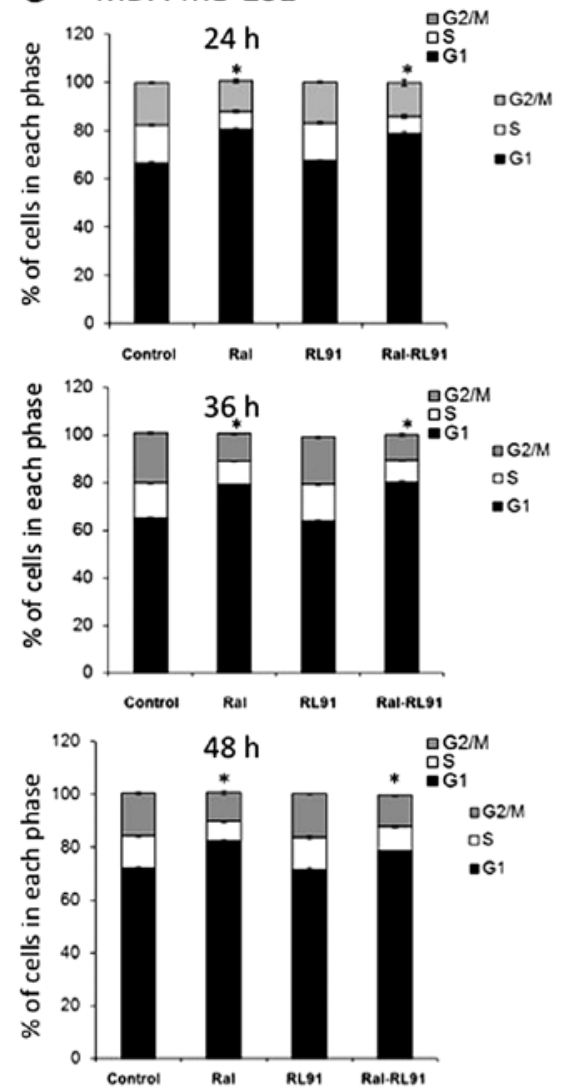

B $\mathrm{SkBr3}$
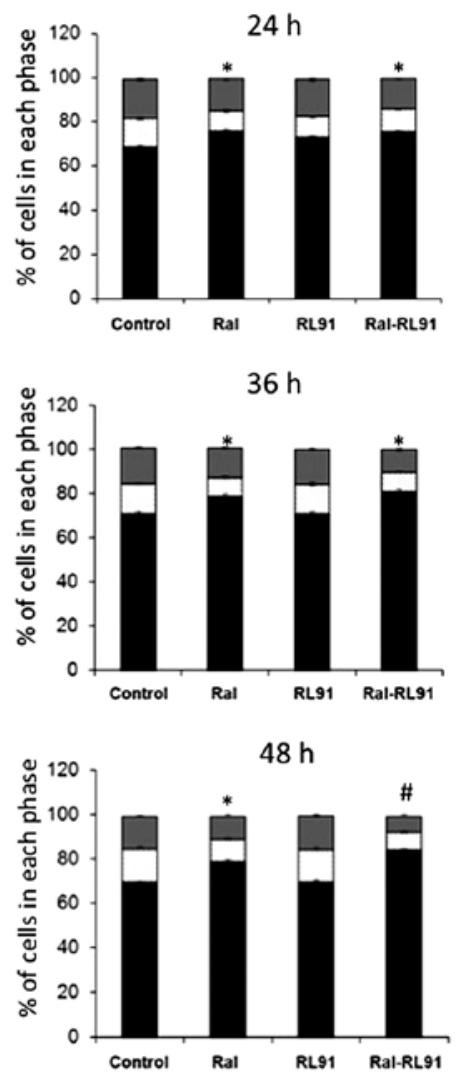

D $\mathrm{MDA}-\mathrm{MB}-468$
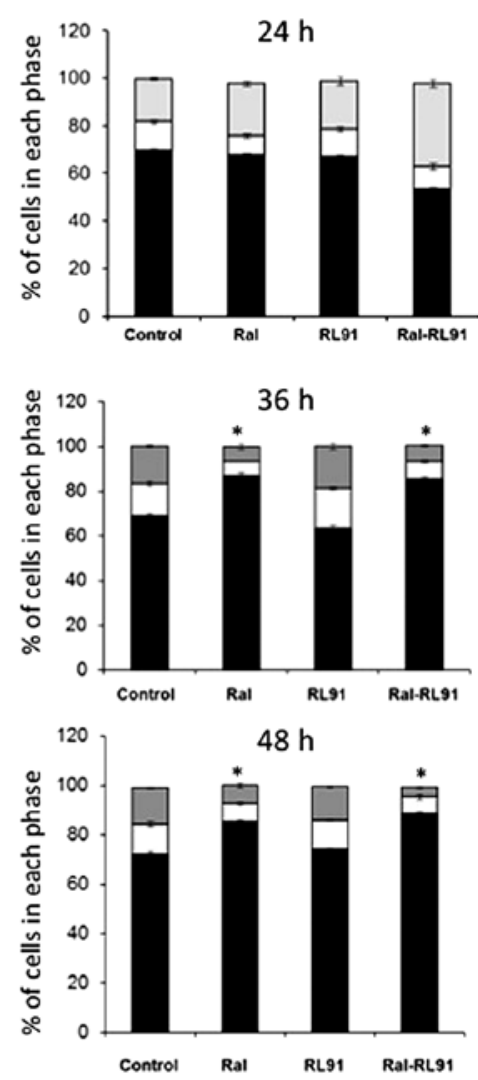

Figure 2. Raloxifene + RL91 arrests ER-negative breast cancer cells in the G1 phase of the cell cycle. Cell were treated with raloxifene (15 $\mu \mathrm{M})$, RL91 (1 $\mu \mathrm{M})$, a combination of the two or $0.1 \%$ DMSO for $24-48 \mathrm{~h}$. Propidium iodide staining and flow cytometry was used to determine the proportion of cells in the various phases of the cell cycle. Bars represent the mean proportion of cells in each phase of cell cycle (\% of total) \pm SEM of 3 independent experiments conducted in triplicate. (A) Hs578t, (B) SKBr3, (C) MDA-MB-231 and (D) MDA-MB-468 cells. Data were analyzed using a two-way ANOVA coupled with a Tukey's post-hoc test. ${ }^{*} \mathrm{P}<0.05$, number of cells in the G1 phase of the cell cycle is significantly increased from control; ${ }^{*} \mathrm{P}<0.05$, number of cells in the G1 phase of the cell cycle are significantly increased from raloxifene. 

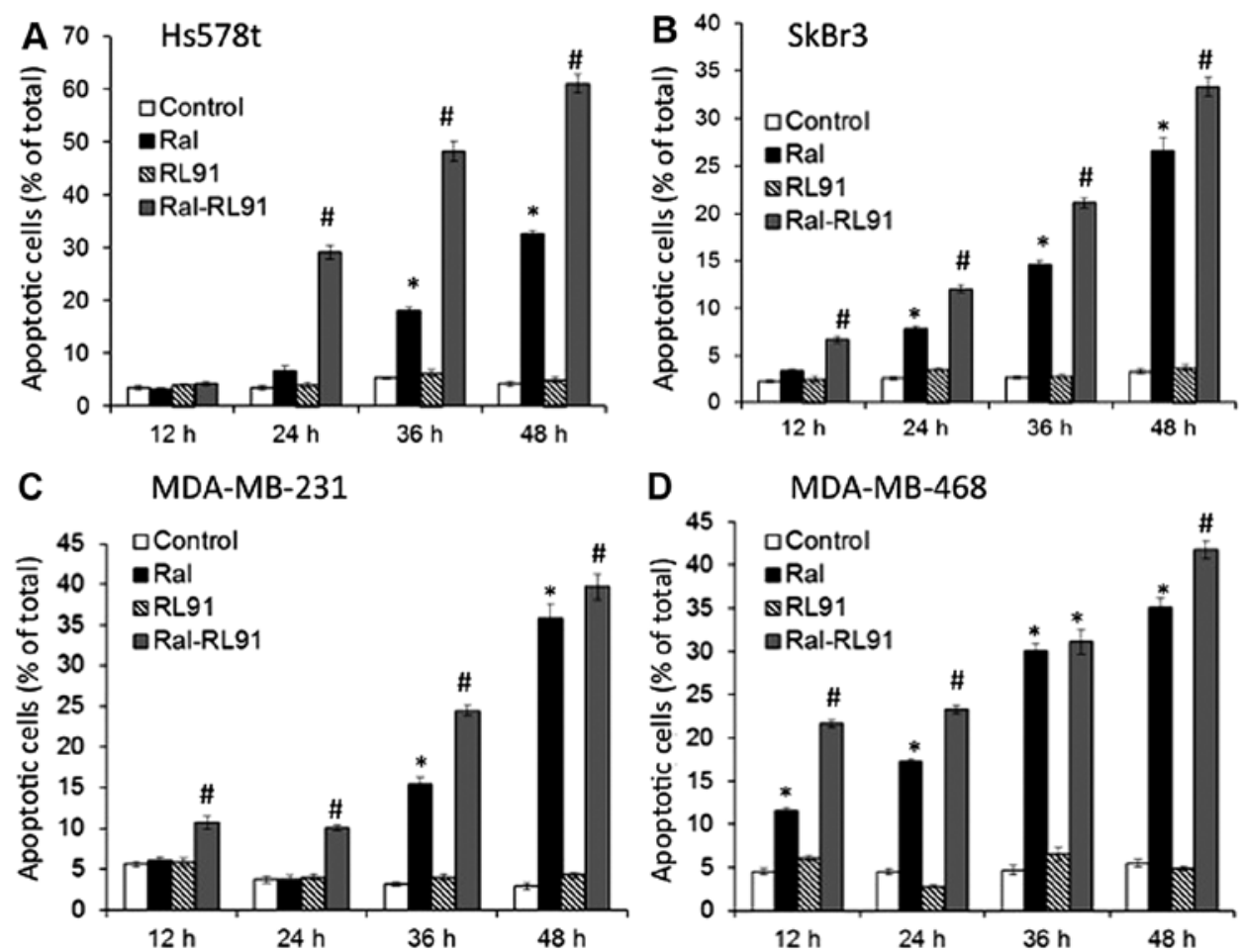

Figure 3. Raloxifene + RL91 synergistically induced apoptosis in ER-negative breast cancer cells. Cell lines were treated with raloxifene (15 $\mu \mathrm{M})$, RL91 $(1 \mu \mathrm{M})$, a combination of the two or $0.1 \%$ DMSO for 12-48 h. Propidium iodide/Annexin V-FITC staining coupled with flow cytometry was used to determine the proportion of cells undergoing apoptosis. Bar represent number of apoptotic cells as a $\%$ of the total number of cells \pm SEM from 3 independent experiments performed in triplicate. (A) Hs578t, (B) SKBr3, (C) MDA-MB-231 and (D) MDA-MB-468 cells. Data were analyzed using a two-way ANOVA coupled with a Tukey's post-hoc test. ${ }^{*} \mathrm{P}<0.05$ significantly increased from control; ${ }^{*} \mathrm{P}<0.05$ significantly increased compared to raloxifene.

cell cycle with the concomitant decrease of the percentage of cells in the $\mathrm{S}$ and G2/M phases (Fig. 2). In Hs578t, SkBr3 and MDA-MB-231 cells the increase in G1 phase cells started at $24 \mathrm{~h}$ and was maintained throughout the treatment period, while in MDA-MB-468 cells, treatment initially potentiated the accumulation of cells in $\mathrm{G} 2 / \mathrm{M}$ phase, before triggering G1 phase accumulation at $36 \mathrm{~h}$ (Fig. 2D). SkBr3 cells were the only cell line where the combination treatment caused a timedependent accumulation of the cells in G1 phase (Fig. 2B).

To determine if the changes in cell cycle progression triggered programmed cell death, we measured apoptosis at different times from 12 up to $48 \mathrm{~h}$. The low concentration of RL91 as a single agent did not induce apoptosis, while raloxifene elicited a time-dependent increase of apoptosis across all cell lines. However, this was cell line-dependent, namely $12 \mathrm{~h}$ for MDA-MB-468, $24 \mathrm{~h}$ for SKBr3 and $36 \mathrm{~h}$ for MDA-MB-231 and HS578t cells. However, after $48 \mathrm{~h} \sim 30-35 \%$ of the cell population was apoptotic across in all cell lines (Fig. 3). However, in all cell lines the combination of the two drugs caused a significantly higher amount of the cell population to become apoptotic but more importantly the combination triggered an early onset of apoptosis. In Hs578t cells, the number of apoptotic cells increased by 7 -fold when compared to other treatment after $24 \mathrm{~h}$ (Fig. 3A). In addition, the percentage of cells undergoing apoptosis increased from 33 to $61 \%$ following $48 \mathrm{~h}$ of treatment with raloxifene and combination, respectively (Fig. 3A). In SkBr3 cells, the combination promoted a higher level of apoptosis at $12 \mathrm{~h}$ and increased up to $48 \mathrm{~h}$ (Fig. 3B). In MDA-MB-231 cells, the combination treatment doubled the number of apoptotic cells at 12 and $24 \mathrm{~h}$ compared to other treatments and was significantly higher than raloxifene at 36 and $48 \mathrm{~h}$ (Fig. 3C). In MDA-MB-468 cells, raloxifene elicited a rapid increase in apoptosis and the combination potentiated this effect, doubling the number of apoptotic cells after $12 \mathrm{~h}$ (Fig. 3D). In all cell lines, the combination increased apoptosis independently of changes in the cell cycle.

We have demonstrated that the suppression of MDA-MB-468 xenograft tumor growth following a daily oral dosing with raloxifene was associated with a decreased EGFR and NF- $\mathrm{KB}$ protein expression (8). Therefore, we postulated that the combination treatment will improve the effect of raloxifene and alter the expression of several proteins essential for either cell survival or apoptosis in all ER-negative cell lines. Notably, in all the cell lines raloxifene and combination enhanced the phosphorylation of members of the mitogen-activated protein kinases (MAPKs) family such as dual specificity mitogenactivated protein kinase kinase-1 (MEK1), extracellular signal-regulated kinase 1/2 (ERK1/2) and stress kinase p38 MAPK (Fig. 4). ERK1/2 is a kinase that phosphorylates a large number of proteins implicated in multiple cellular processes including apoptosis (17). p38 MAPK is activated in response to cellular stresses and depending on the cell line may affect multiple cellular processes including cell cycle arrest and apoptosis. Across all the cell lines, the different treatments did not alter the total level of expression of these kinases. Furthermore, the phosphorylation of these kinases varied upon the treatment, time and cell lines. In MDA-MB-231 cells, the basal level of MEK1 phosphorylation is high and its amplification following raloxifene and combination treatment is observed only after $36 \mathrm{~h}$. The enhancement of MEK phosphorylation 


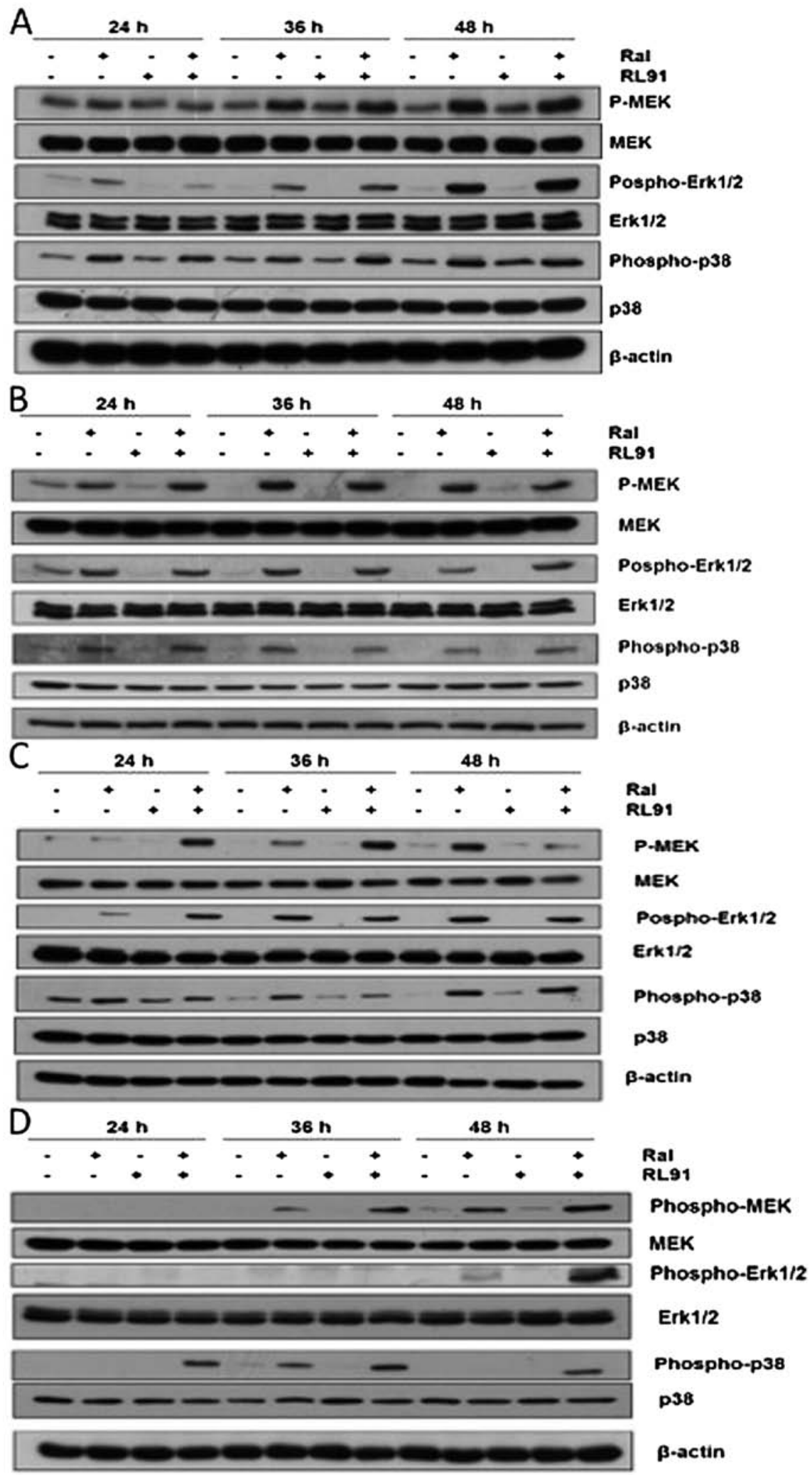

Figure 4. Raloxifene + RL91 modulates the expression of mitogen-activated protein kinases in ER-negative breast cancer cells. ER-negative breast cancer cells were treated with raloxifene $(15 \mu \mathrm{M})$, RL91 $(1 \mu \mathrm{M})$, a combination of the two or $0.1 \%$ DMSO for 24-48 $\mathrm{h}$. Total cell lysates were analyzed by western blotting with the specific antibodies and $\beta$-actin served as the loading control. Representative blots from $n=3$ preformed in triplicate are shown. (A) MDA-MB-231 cells, (B) MDA-MB-468 cells, (C) Hs578t cells and (D) SkBr3 cells.

triggers phosphorylation of ERK1/2, downstream of MEK1 in the MAPK signaling cascade. Furthermore, this effect was enhanced by the combination with RL91. In addition, p38 MAPK follows the phosphorylation pattern of MEK, where combination treatment amplified p38 MAPK phosphorylation after 36 and $48 \mathrm{~h}$ (Fig. 4A). In MDA-MB-468 cells, raloxifene and combination increased MEK phosphorylation up to $48 \mathrm{~h}$. However, the combination triggered a higher increase of MEK 


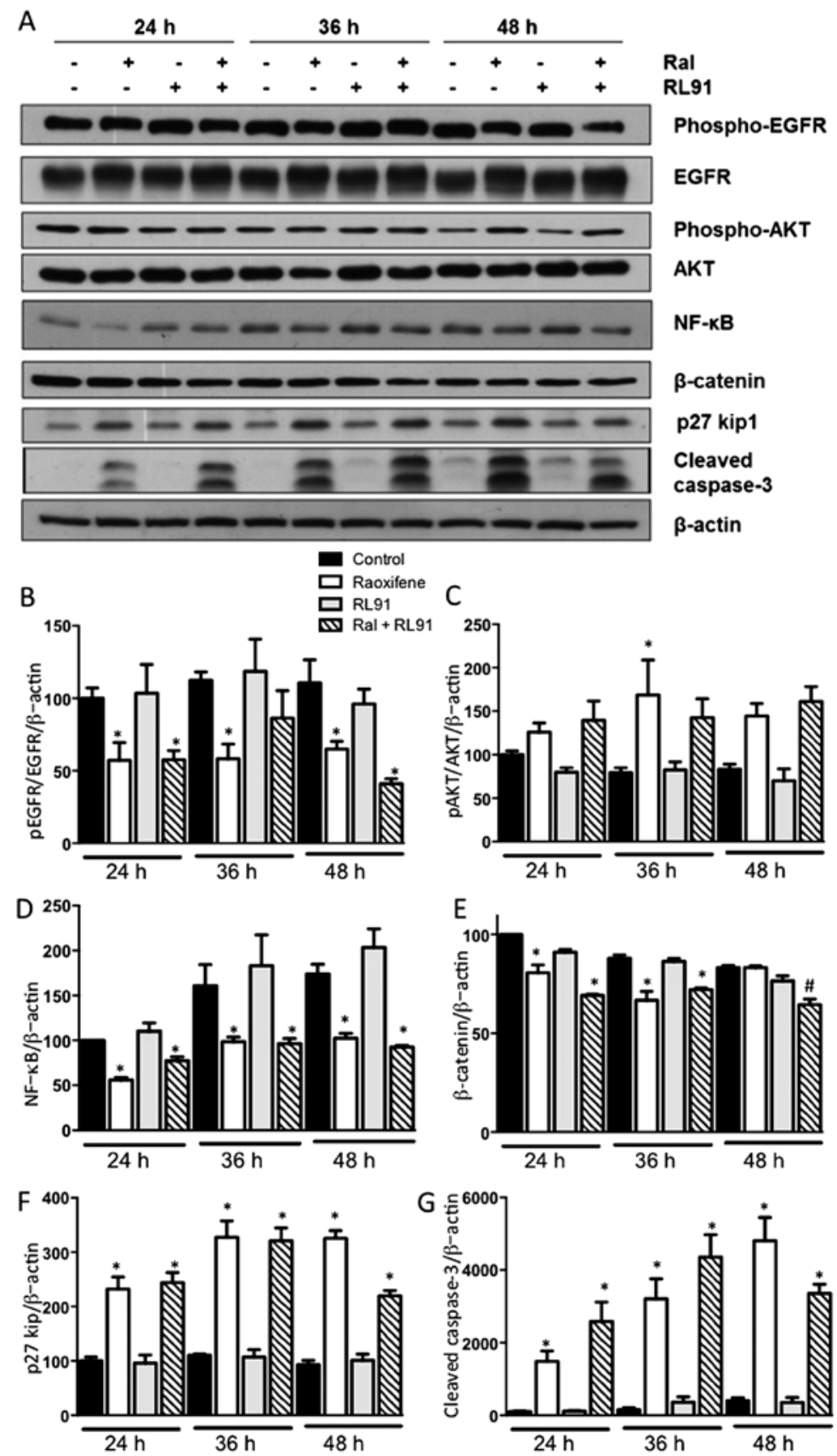

Figure 5. Raloxifene + RL91 modulates the expression of proteins essential for cancer cell proliferation, protein synthesis and apoptosis in MDA-MB-468 cells. MDA-MB-468 cells were treated with raloxifene $(15 \mu \mathrm{M})$, RL91 $(1 \mu \mathrm{M})$, a combination of the two or 0.1\% DMSO for 24-48 h. Total cell lysates were analyzed by western blotting with the specific antibodies and $\beta$-actin served as the loading control. (A) Representative blots, scanning densitometry for (B) EGFR, (C) AKT, (D) NF-kB, (E) $\beta$-catenin, (F) p27kip and (G) cleaved caspase-3. Bars represent the mean \pm SEM of 3 independent experiments conducted in triplicate. ${ }^{*} \mathrm{P}<0.05$ significantly different from control; ${ }^{*} \mathrm{P}<0.05$ significantly different compared to all other treatments.

phosphorylation at $24 \mathrm{~h}$. ERK1/2 and p38 MAPK follow an identical phosphorylation pattern where raloxifene and combination promote and sustain their phosphorylation (Fig. 4B). In Hs578t cells, the phosphorylation of MEK is more transient and amplified by the combination treatment at 24 and $36 \mathrm{~h}$ while being reduced at $48 \mathrm{~h}$. The effect of raloxifene treatment on MEK phosphorylation was more progressive and peaked at $48 \mathrm{~h}$. As a consequence, ERK1/2 phosphorylation was rapidly increased after $24 \mathrm{~h}$ and plateaued up to $48 \mathrm{~h}$ following combination treatment while raloxifene triggered a more progressive increment of ERK1/2 phosphorylation. Phosphorylation of p38 MAPK was sustained following raloxifene treatment from 24 to $48 \mathrm{~h}$ when compared to the combination (Fig. 4C). Finally, in $\mathrm{SkBr} 3$ cells the phosphorylation of MEK was not enhanced by combination treatment until $36 \mathrm{~h}$ but was increased further at $48 \mathrm{~h}$. Raloxifene promotes only a modest increase at 36 and $48 \mathrm{~h}$. Phosphorylation of p38 was more transient and was only induced by the combination at $24 \mathrm{~h}$, raloxifene induced a transient p38 MAPK phosphorylation at $36 \mathrm{~h}$. Overall, the levels of phosphorylation of MEK, ERK1/2 or p38 MAPK poorly correlate with the accumulation of the cells in G1 of the cell cycle or apoptosis but coincide with the activation of caspase- 3 (Fig. 5). Furthermore, the combination treatment of raloxifene with an inhibitor of MEK (U0126) or p38 MAPK (SB203580) 

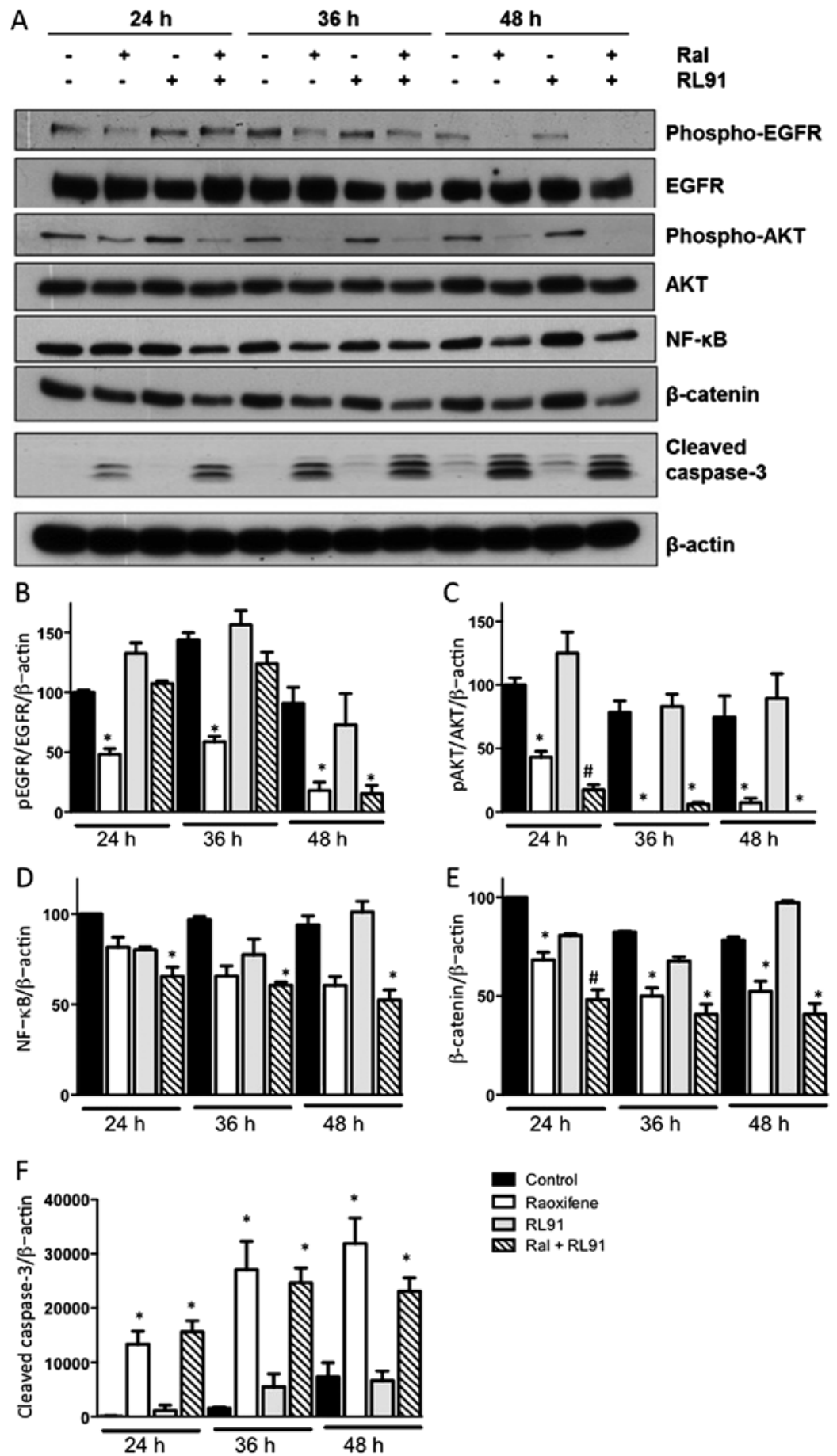

Ral + RL9

Figure 6. Raloxifene + RL91 modulates the expression of proteins essential for cancer cell proliferation, protein synthesis and apoptosis in MDA-MB-231 cells. MDA-MB-231 cells were treated with raloxifene $(15 \mu \mathrm{M})$, RL91 $(1 \mu \mathrm{M})$, a combination of the two or 0.1\% DMSO for 24-48 h. Total cell lysates were analyzed by western blotting with the specific antibodies and $\beta$-actin served as the loading control. (A) Representative blots, (B) scanning densitometry for EGFR, (C) AKT, (D) NF-кB, (E) $\beta$-catenin and (F) cleaved caspase-3. Bars represent the mean \pm SEM of 3 independent experiments conducted in triplicate. ${ }^{*} \mathrm{P}<0.05$ significantly different from control; ${ }^{*} \mathrm{P}<0.05$ significantly different compared to all other treatments.

in MDA-MB-231, HS578t and MDA-MB-468 cells did not reduce the cytotoxicity of raloxifene (data not shown).

We then assessed the effect of raloxifene and its combination with RL91 on the expression of EGFR and its downstream effectors. In MDA-MB-468 cells, raloxifene $(15 \mu \mathrm{M})$ significantly decreased EGFR phosphorylation at amino acid Tyr1148 but this was not enhanced by co-treatment with RL91 (Fig. 5B). EGFR is phosphorylated at multiple sites and Tyr1148 is generally associated with the activation of MAP kinase signaling pathway. Contrary to the other cell lines, MDA-MB-468 cells are characterized by the lack of PTEN expression, a key regulator of AKT activity (18), we observed that the treatment with raloxifene and combination did not affect total AKT expression but raloxifene increased phosphorylation of AKT at $36 \mathrm{~h}$ (Fig. 5C). The enhanced phosphorylation suggests that raloxifene affects the feedback loop regulation of AKT and promoted cumulative phosphorylation. The increased AKT phosphorylation may be responsible for 


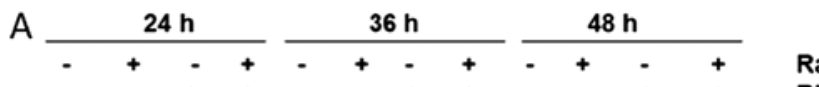

$\begin{array}{lllllllllllll}- & + & - & + & - & + & - & + & - & + & - & + & \text { Ral } \\ - & - & + & + & - & - & + & + & - & - & + & + & \end{array}$

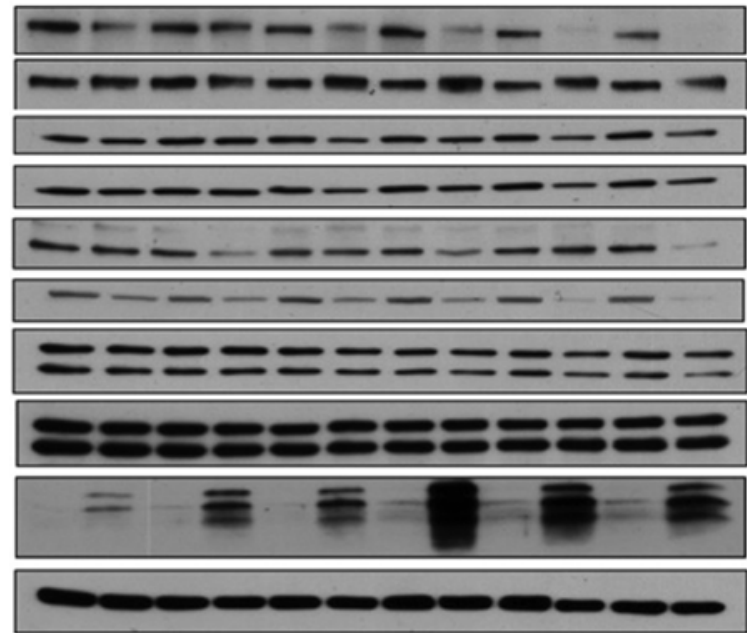

Phospho-EGFR

EGFR

Phospho-AKT

AKT

NF-KB

$\beta$-catenin

Phospho-GSK3 $\alpha / \beta$

GSK3 $\alpha / \beta$

Cleaved

caspase-3

$\beta$-actin

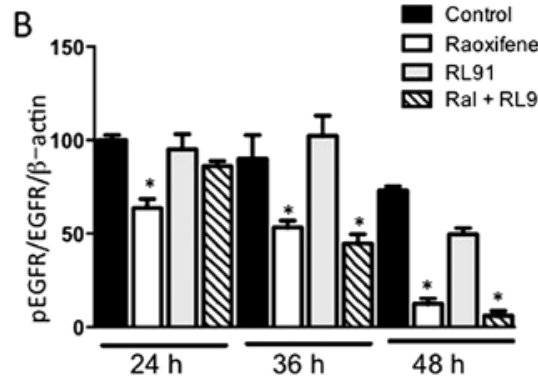

C
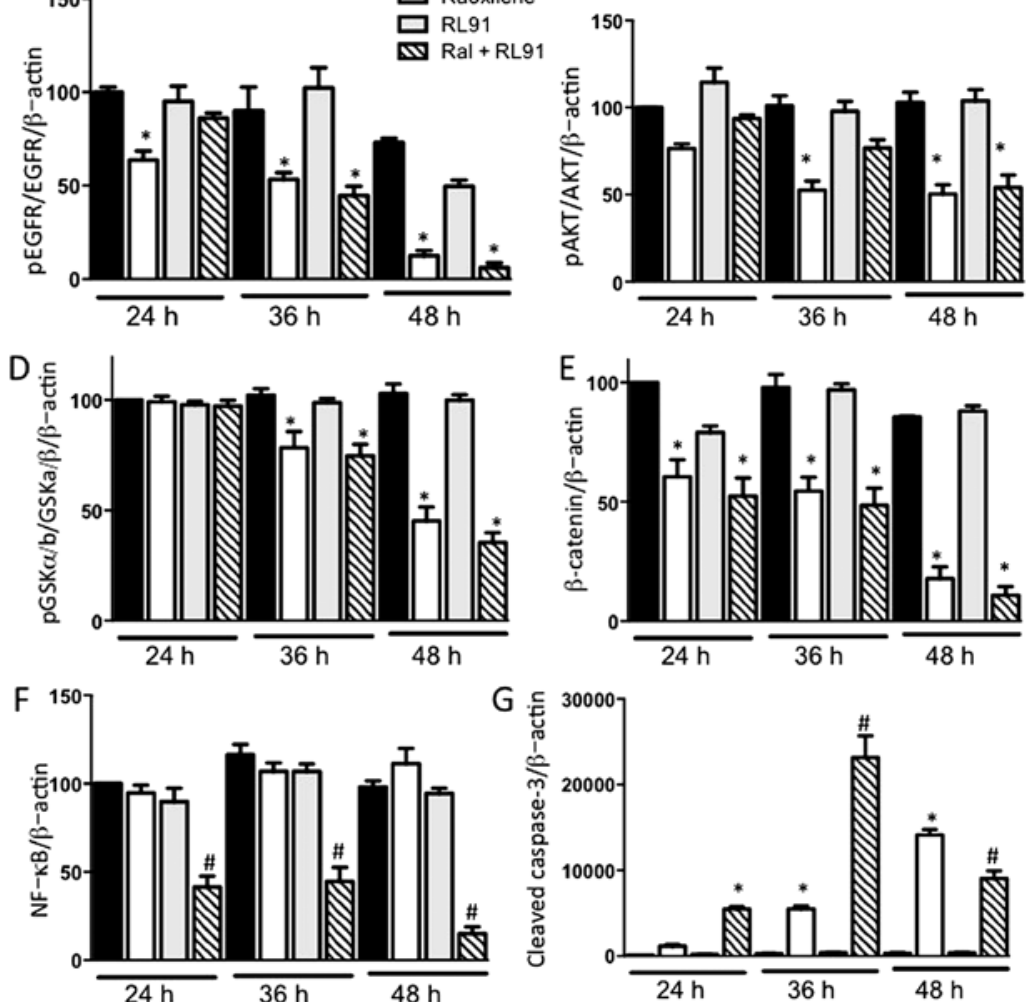

Figure 7. Raloxifene + RL91 modulates the expression of proteins essential for cancer cell proliferation, protein synthesis and apoptosis in HS578t cells HS578t cells were treated with raloxifene $(15 \mu \mathrm{M})$, RL91 $(1 \mu \mathrm{M})$, a combination of the two or $0.1 \%$ DMSO for $24-48 \mathrm{~h}$. Total cell lysates were analyzed by western blotting with the specified antibodies and $\beta$-actin served as a loading control. (A) Representative blots, scanning densitometry for (B) EGFR, (C) AKT, (D) GSK $\alpha / \beta$, (E) $\beta$-catenin, (F) NF- $\kappa \mathrm{B}$ and (G) cleaved caspase-3. Bars represent the mean \pm SEM of 3 independent experiments conducted in triplicate. ${ }^{*} \mathrm{P}<0.05$ significantly different from control; ${ }^{*} \mathrm{P}<0.05$ significantly different compared to all other treatments.

the stabilization of $\beta$-catenin protein, but did not prevent the decrease of NF- $\mathrm{kB}$ expression following raloxifene and combination treatment from $24 \mathrm{~h}$ (Fig. 5D). In addition, both raloxifene and combination increased expression of p27Kip1 after $24 \mathrm{~h}$ (Fig. 5F). The protein is an inhibitor of cell cycle progression and promotes accumulation of the cells in G1 phase. The enhanced expression of p27Kip1 was not observed in the other cell lines. Finally, the activation of caspase-3, a hallmark of the apoptotic process, was observed as soon as
$12 \mathrm{~h}$ following raloxifene treatment and potentiated by its combination with RL91 (Fig. 5G).

In MDA-MB-231 cells, raloxifene and combination treatment decreased the phosphorylation of EGFR from 24-48 $\mathrm{h}$ without significantly affecting total EGFR expression (Fig. 6B). AKT expression and phosphorylation was reduced following raloxifene treatment while combination of raloxifene with RL91 potentiated the reduction of its phosphorylation at $24 \mathrm{~h}$ (Fig. 6C). Expressions of NF- $\mathrm{KB}$ and $\beta$-catenin, proteins regu- 
A

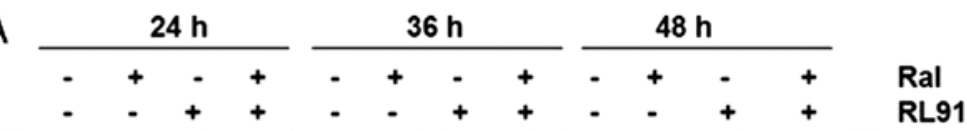

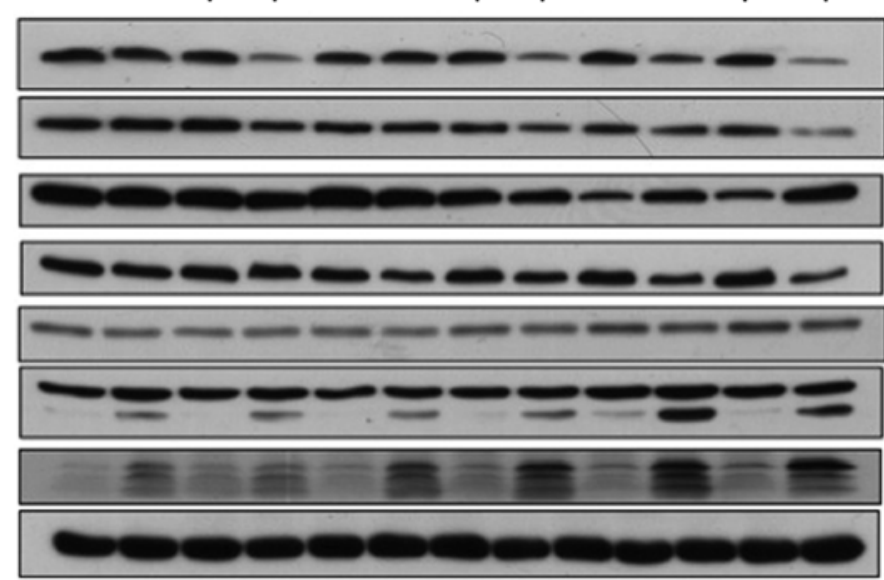

Phospho-Her2

Her2

Phospho-AKT

AKT

NF-KB

$\beta$-catenin

\section{Cleaved}

caspase-3

$\beta$-actin
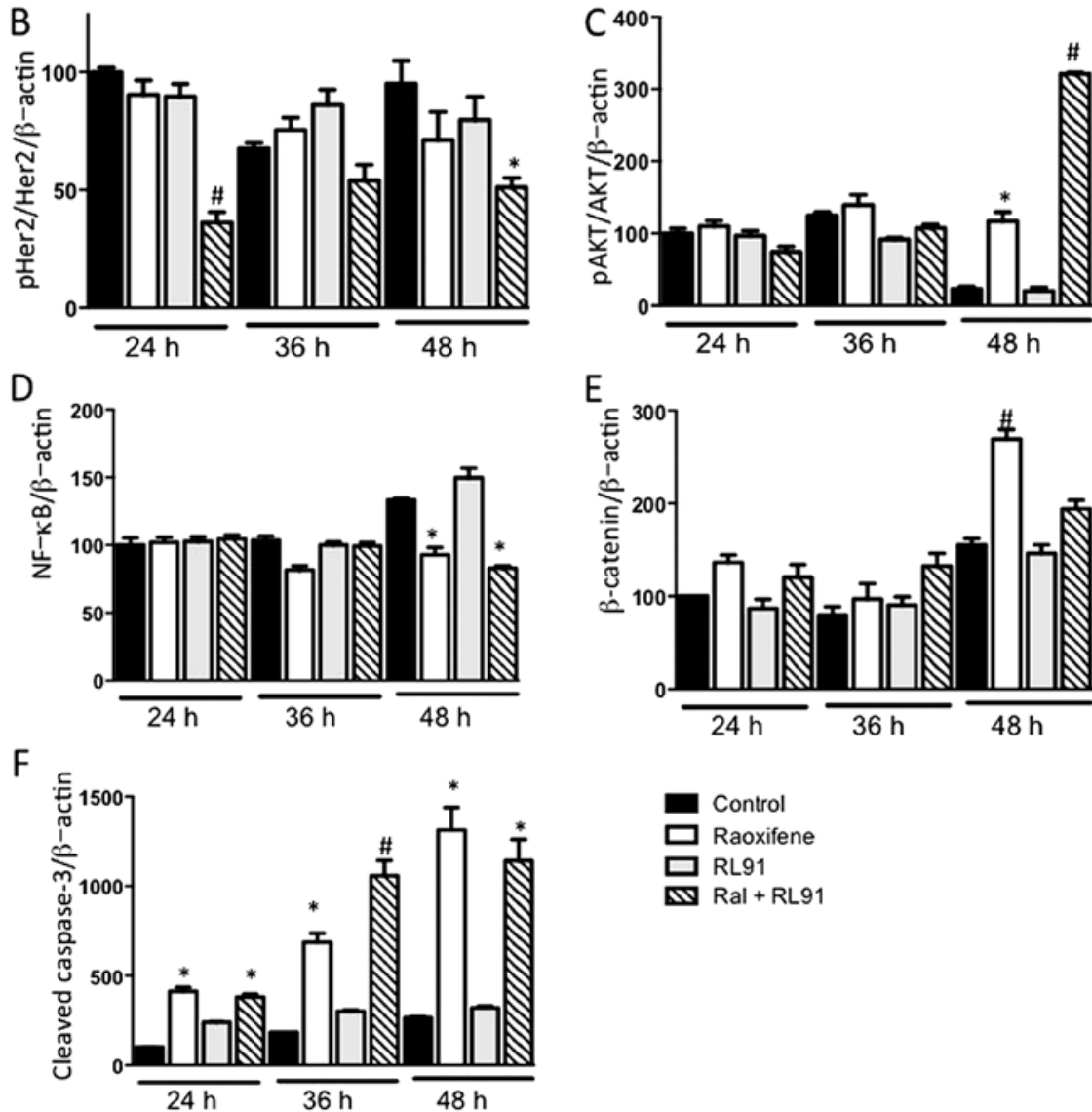

Figure 8. Raloxifene + RL91 modulates the expression of proteins essential for cancer cell proliferation, protein synthesis and apoptosis in SKBr3 cells. SKBr3 cells were treated with raloxifene $(15 \mu \mathrm{M})$, RL91 $(1 \mu \mathrm{M})$, a combination of the two or $0.1 \%$ DMSO for $24-48 \mathrm{~h}$. Total cell lysates were analyzed by western blotting with the specified antibodies and $\beta$-actin served as a loading control. (A) Representative blots, (B) Her2, (C) AKT, (D) NF-kB, (E) $\beta$-catenin and $(\mathrm{F})$ cleaved caspase-3. Bars represent the mean \pm SEM of 3 independent experiments conducted in triplicate. ${ }^{*} \mathrm{P}<0.05$ significantly different from control; ${ }^{\text {"}} \mathrm{P}<0.05$ significantly different compared to all other treatments.

lated by AKT, were reduced by raloxifene after 36 and $48 \mathrm{~h}$ (Fig. 6DE), while the combination decreased the expression at 24 h. Similar to MDA-MB-468 cells, cleaved caspase-3 was induced following raloxifene and potentiated by the combination at $24 \mathrm{~h}$ (Fig. 6F).

In Hs578t cells, the combination treatment also significantly decreased the phosphorylation and total EGFR (Fig. 7B) and AKT (Fig. 7C) expression to a similar extent as raloxifene alone. Notably, phosphorylation of GSK $3 \alpha / \beta$, whose level is regulated by AKT, was reduced following raloxifene and combination treatments (Fig. 7D). Dephosphorylation of GSK $3 \alpha / \beta$ is generally associated with increased activity of the kinase and is responsible for the phosphorylation and degradation of $\beta$-catenin. The expression of $\beta$-catenin decreased following raloxifene and combination treatments (Fig. 7E), corresponding to the dephosphorylation profile of GSK $3 \alpha / \beta$. 


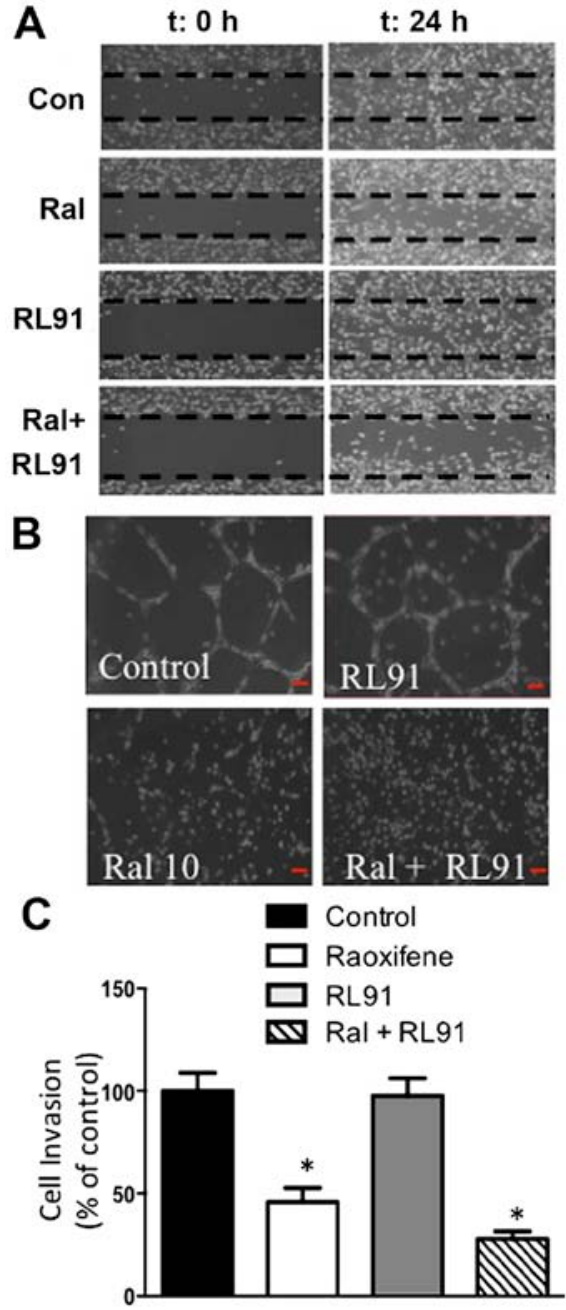

Figure 9. Raloxifene + RL91 inhibits cell migration, endothelial tube formation and invasion in vitro. (A) Scratch assay for cell migration. A confluent MDA-MB-231 cell monolayer was wounded and incubated for $20 \mathrm{~h}$ with raloxifene $(10 \mu \mathrm{M})$, RL91 $(1 \mu \mathrm{M})$ or a combination of the two or DMSO $(0.1 \%)$. Representative monolayer images from three independent experiments performed in triplicate are shown at 0 and $20 \mathrm{~h}$. Cell invasion assay. (B) Tube formation of HUVEC cells. HUVEC cells $(50,000 /$ well) were seeded and treated with raloxifene $(10 \mu \mathrm{M})$, RL91 $(1 \mu \mathrm{M})$, a combination of the two or DMSO $(0.1 \%)$ for $18 \mathrm{~h}$. Images were taken by an examiner blinded to the treatment groups. Representative images from three independent experiments performed in triplicate are shown. (C) MDA-MB-231 cells were seeded onto filters precoated with Matrigel on the upper surface in Transwell chambers and treated with raloxifene $(10 \mu \mathrm{M})$, RL91 $(1 \mu \mathrm{M})$, a combination of the two or $0.1 \%$ DMSO. The bottom chamber contained growth media with $5 \% \mathrm{FBS}$ as the chemoattractant. After $20 \mathrm{~h}$ the cells migrating to the lower surface were fixed, stained with Diff Quick and counted. The bars represent the mean \pm SEM of three independent experiments performed in triplicate ${ }^{*} \mathrm{P}<0.05$ significantly different to vehicle control.

$\mathrm{NF}-\kappa \mathrm{B}$ expression was only reduced by the combination treatment (Fig. 7F). As in the other cell lines, the activation of caspase- 3 was also potentiated by the combination when compared to raloxifene treatment at $24 \mathrm{~h}$ (Fig. 7G).

$\mathrm{SkBr} 3$ cells are characterized by the overexpression of HER2, an isoform of EGFR. In these cells, the combination treatment significantly decreased the phosphorylation and HER2 protein expression at $24 \mathrm{~h}$, while raloxifene decreased its expression at $48 \mathrm{~h}$ (Fig. 8B). Raloxifene and combination treatments reduced the expression of AKT while increasing its phosphorylation at $48 \mathrm{~h}$ (Fig. 8C). The deregulation of AKT phosphorylation was not associated with a lack or mutation of PTEN protein as these cells expressed the wild-type protein. We also observed decreased $\mathrm{NF}-\kappa \mathrm{B}$ expression following raloxifene and combination treatments (Fig. 8D). Interestingly, raloxifene and combination did not reduce the expression of $\beta$-catenin but triggered the appearance of a truncated form of the protein (Fig. 8E). Additionally, cleaved caspase-3 was increased after $24 \mathrm{~h}$ following both raloxifene and combination. The activation of caspase- 3 was enhanced by the combination when compared to raloxifene after 36 to $48 \mathrm{~h}$ (Fig. 8F).

To determine if the combination treatment could potentially alter metastasis, two different in vitro assays were performed. Specifically, MDA-MB-231 cell migration was examined using the scratch assay while MDA-MB-231 cell invasion was determined using transwell cell invasion. All of these assays when combined give an indication of how well a drug may modulate metastasis in vivo. In these assays RL91 $(1 \mu \mathrm{M})$ was ineffective, while raloxifene $(10 \mu \mathrm{M})$ decreased scratch closure and decreased the number of invasive cells by $54 \pm 7 \%$ (Fig. 9A and B). The combination suppressed cell migration and decreased invasion by $18 \%$ compared to raloxifene but this was not statistically significant. Finally, we assessed the effect of the combination on angiogenesis using an endothelial cell tube-like formation assay. RL91 has no effect on the endothelial tube formation while raloxifene and combination treatment abolished endothelial cell extension (Fig. 9C).

\section{Discussion}

We have demonstrated that in the absence of ER- $\alpha$ expression, raloxifene promoted cell cycle arrest in the G1 phase, increased apoptosis and internalization of plasma membrane associated EGFR into cytoplasmic vesicles in vitro (8). We also showed that raloxifene elicits the reduction of xenograft tumor growth which was associated with a decrease in EGFR expression, an increase apoptosis, and reduction in angiogenesis in vivo (8). Triple-negative breast cancers, represented in this study by MDA-MB-231, MDA-MB-468 and Hs578t cells, are characterized by their lack of responsiveness to multiple ligands (19) and, therefore, respond poorly to targeted therapies. Our laboratory has developed a range of second-generation curcumin derivatives that exhibit potent cytotoxicity $(13,20)$ in ER-negative breast cancer cell lines and target multiple signaling pathways in vitro (13-15). Therefore, the present study was designed to determine if a low concentration of RL91 could enhance the anticancer properties of raloxifene in a range of ER-negative breast cancer cell lines. Our results showed that RL91 enhanced the cytotoxicity elicited by raloxifene in all ER-negative breast cancer cell lines. Importantly, in all cell lines cytotoxicity and apoptosis were always produced either earlier or amplified by the combination treatment compared to raloxifene alone, as shown by both flow cytometery and cleaved caspase- 3 activation. The effects of the different treatments on cell cycle progression are independent from the commitment of the cell to the apoptotic pathway. In Hs578t and MDA-MB-231 cells, raloxifene increased apoptosis only after $36 \mathrm{~h}$ while G1 accumulation was observed after $24 \mathrm{~h}$. Similar to results seen with other 2 nd generation curcumin derivatives $(14,15,17)$ and combination therapy with tamoxifen and raloxifene $(10,11,21)$, cell cycle arrest did not 
drive apoptosis. In fact, significant apoptosis developed regardless of G2 arrest, elicited by curcumin derivatives (13-15), or G1 arrest, elicited by raloxifene (10), or by the combination of raloxifene and RL91.

The cellular stress triggered by the cytotoxic drugs may promote cell cycle arrest in the G1 phase. In all cell lines, the treatment with raloxifene and its combination with RL91 promote the activation of p38 MAPK. The p38 MAPK is activated by a broad range of stress stimuli (22) and has been associated with the inhibition of cell cycle progression and induction of apoptosis $(9,23)$. The activation of p38 MAPK was observed in all cell lines as early as $24 \mathrm{~h}$ by raloxifene and the combination treatments, excepted in $\mathrm{SkBr} 3$ cells where phosphorylation of p38 MAPK induced by raloxifene treatment was transient. The inhibition of p38 MAPK by the specific inhibitor SB203580, did not alter the cytotoxic profile of raloxifene (data not shown), suggesting that the activation p38 MAPK essentially promotes the cell cycle arrest. In MDA-MB-468 cells only, the treatment by raloxifene and combination enhanced the expression of $\mathrm{p} 27 \mathrm{Kip} 1$, a negative regulator of the G1 to S phase transition (24).

The overexpression or mutation of EGFR has been identified in multiple cancer types. In ER-negative breast cancer, the EGFR is especially important, as it is overexpressed in cell lines $(25,26)$ and $50 \%$ of tumors $(27-29)$. Previous studies showing that both raloxifene and RL91 modulate the EGFR expression and downstream cell signaling proteins formed the basis of the molecular mechanisms examined in the present study. Furthermore, EGFR controls many basic cellular functions including cell proliferation, survival, mobility and migration, and also promotes the establishment of new blood vessels (angiogenesis) that provide oxygen and nutrients to the tumor (30). The Ras/Raf/MEK/ERK1/2 and Ras/PI3K/AKT signaling cascades are critical to these physiological processes.

The activation of ERK1/2 is generally associated with cell proliferation and resistance to apoptosis. However, in all cell lines, raloxifene treatment increased phosphorylation of MEK and ERK1/2, the effect of raloxifene was enhanced by the combination with RL91. The activation of ERK1/2 can also contribute to the enhancement of cell death through activation of caspase-3 and suppression of AKT signaling (31). Several therapeutic agents have also been associated with an increase of ERK1/2 phosphorylation such as Taxol (32), doxorubicin (33), resveratrol (34) and quercetin (35). The implication of ERK1/2 in the apoptotic process may be the result of the change in the amplitude, duration and frequency of its phosphorylation or even localization (36). In all the triple-negative breast cancer cell lines used in the present study, the increase in the phosphorylation of ERK1/2 coincided with the onset of apoptosis. However, in SkBr3 cells, the increased ERK1/2 phosphorylation occurs at a later time point suggesting that additional factors contribute to the increase of apoptosis following raloxifene and combinations treatments. Furthermore, co-treatment of triple-negative breast cancer cell lines of raloxifene with the MEK inhibitor U0126, failed to decrease the cytotoxicity of raloxifene (data not shown).

The treatment with raloxifene and combination also affected the AKT signaling cascade. In MDA-MB-231 cells, RL91 enhanced the ability of raloxifene to decrease the downstream effector of EGFR signaling pathway such as AKT implicated in the regulation of $\beta$-catenin and $\mathrm{NF}-\kappa \mathrm{B}$. AKT has been implicated in a myriad of regulatory mechanisms involving protein synthesis, cell cycle progression and inhibition of apoptosis $(37,38)$ by promoting the expression of anti-apoptotic proteins such as Bcl-xL, c-Myb and caspase inhibitors $(39,40)$. Recent studies have also suggested that a decrease in the level of AKT could lead to higher activity of p38 MAPK (41) and this protein was increased in response to raloxifene and combination from $24 \mathrm{~h}$ onwards.

This trend was examined in the other ER-negative cell lines. In MDA-MB-468 and SKBr3 cells, AKT phosphorylation was not decreased at $48 \mathrm{~h}$, while in control and RL91 treated cells the phosphorylation of AKT was reduced. MDA-MB-468 cells lack the expression of the PTEN protein, a tumor suppressor protein which negatively regulates the AKT pathway (42). In addition, $\mathrm{SkBr} 3$ cells are characterized by their low PTEN expression (43). Hs578t cells responded the best to combination treatment as EGFR was decreased $94 \%$ at $48 \mathrm{~h}, \mathrm{NF}-\kappa \mathrm{B}$ was significantly decreased compared to all other treatments at all time points and $\beta$-catenin was decreased to the largest extent $(94 \%)$ at $48 \mathrm{~h}$. Additionally, GSK $3 \alpha / \beta$ was decreased by $65 \%$ following combination treatment after $48 \mathrm{~h}$. GSK $3 \alpha / \beta$ kinase is negatively regulated by AKT and plays a pivotal role in the stability of $\beta$-catenin (44). The decreased phosphorylation is associated with the increased activity of the kinase promoting $\beta$-catenin phosphorylation and degradation (44).

We also examined the effect of the combination therapy in $\mathrm{SkBr} 3$ cells because breast cancer patients whose tumors overexpress HER2/neu have a poor prognosis, shorter relapse time and shorter survival time (27). Additionally, our curcumin derivatives have shown potent suppression of HER2 in $\mathrm{SkBr} 3$ cells (13-15). The results showed that the combination reduced HER 2 expression and phosphorylation earlier than raloxifene alone ( 24 vs. 48 h). The decrease of HER2 expression was also time-dependent. While the combination therapy decreased HER 2 by $64 \%$ at $24 \mathrm{~h}$, it was not more potent than other curcumin analogs at downregulating the expression of HER2, as $1 \mu \mathrm{M}$ of RL71 (15) and $10 \mu \mathrm{M}$ concentrations of and FLLL11 and FLLL12 (45) decreased HER2 92\% at $24 \mathrm{~h}$. However, since RL91 at $4 \mu \mathrm{M}$ also decreased HER2 $99 \%$ in $\mathrm{SkBr} 3$ cells (13) a higher concentration of RL91 may elicit a stronger response in combination with raloxifene.

To determine if RL91 could enhance the anti-metastatic and anti-angiogenic properties of raloxifene, we examined the effect of the drug combination in multiple in vitro assays. Importantly, combination treatment had a significant inhibitory effect on MDA-MB-231 cell migration and invasion as well as endothelial tube formation demonstrating an anti-metastatic and anti-angiogenic effect of the combination treatment. This is not that surprising because in a xenograft model of ER-negative breast cancer raloxifene not only decreased tumor growth but also decreased the number of CD105-positive cells in the tumors, a marker of endothelial cells and neoangiogenesis (8). Overall our results show that RL91 enhances the cytotoxicity and growth suppressive effects of raloxifene and causes an increase in the number of apoptotic cells. The combination targeted multiple proteins across all the cell lines and appears to reduce the metastatic potential of cancer cell lines and may 
be sufficient to reduce the formation of new blood vessels. A combination with RL91 warrants further examination in in vivo models of ER-negative breast cancer, as it may be a better strategy to address intratumoral heterogeneity.

\section{Acknowledgements}

The present study was supported by grants from the Otago Medical Research Foundation (RJR and ST) and the Breast Cancer Cure Research Trust (RJR).

\section{References}

1. Sporn MB, Dowsett SA, Mershon J and Bryant HU: Role of raloxifene in breast cancer prevention in postmenopausal women: Clinical evidence and potential mechanisms of action. Clin Ther 26: 830-840, 2004.

2. Jordan VC and Koerner S: Inhibition of oestradiol binding to mouse uterine and vaginal oestrogen receptors by triphenylethylenes. J Endocrinol 64: 193-194, 1975.

3. Croxtall JD, Emmas C, White JO, Choudhary Q and Flower RJ: Tamoxifen inhibits growth of oestrogen receptor-negative A549 cells. Biochem Pharmacol 47: 197-202, 1994.

4. Couldwell WT, Weiss MH, DeGiorgio CM, Weiner LP, Hinton DR, Ehresmann GR, Conti PS, Apuzzo ML and Apuzzo MLJ: Clinical and radiographic response in a minority of patients with recurrent malignant gliomas treated with high-dose tamoxifen. Neurosurgery 32: 485-489, discussion 489-490, 1993

5. Del Prete SA, Maurer LH, O'Donnell J, Forcier RJ and LeMarbre P: Combination chemotherapy with cisplatin, carmustine, dacarbazine, and tamoxifen in metastatic melanoma. Cancer Treat Rep 68: 1403-1405, 1984.

6. Murphy LC and Sutherland RL: Differential effects of tamoxifen and analogs with nonbasic side chains on cell proliferation in vitro. Endocrinology 116: 1071-1078, 1985.

7. Plowman PN: Tamoxifen as adjuvant therapy in breast cancer. Current status. Drugs 46: 819-833, 1993.

8. Taurin S, Allen KM, Scandlyn MJ and Rosengren RJ: Raloxifene reduces triple-negative breast cancer tumor grow th and decreases EGFR expression. Int J Oncol 43: 785-792, 2013.

9. Mandlekar S and Kong ANT: Mechanisms of tamoxifen-induced apoptosis. Apoptosis 6: 469-477, 2001.

10. Stuart EC and Rosengren RJ: The combination of raloxifene and epigallocatechin gallate suppresses growth and induces apoptosis in MDA-MB-231 cells. Life Sci 82: 943-948, 2008.

11. Stuart EC, Jarvis RM and Rosengren RJ: In vitro mechanism of action for the cytotoxicity elicited by the combination of EGCG and raloxifene in MDA-MB-231 cells. Oncol Rep 24: 779-785, 2010.

12. Anzano MA, Peer CW, Smith JM, Mullen LT, Shrader MW, Logsdon DL, Driver CL, Brown CC, Roberts AB and Sporn MB Chemoprevention of mammary carcinogenesis in the rat: Combined use of raloxifene and 9-cis-retinoic acid. J Natl Cancer Inst 88: 123-125, 1996.

13. Somers-Edgar TJ, Taurin S, Larsen L, Chandramouli A, Nelson MA and Rosengren RJ: Mechanisms for the activity of heterocyclic cyclohexanone curcumin derivatives in estrogen receptor negative human breast cancer cell lines. Invest New Drugs 29: 87-97, 2011.

14. Yadav B, Taurin S, Larsen L and Rosengren RJ: RL66 a secondgeneration curcumin analog has potent in vivo and in vitro anticancer activity in ER-negative breast cancer models. Int $\mathrm{J}$ Oncol 41: 1723-1732, 2012.

15. Yadav B, Taurin S, Larsen L and Rosengren RJ: RL71, a second-generation curcumin analog, induces apoptosis and downregulates Akt in ER-negative breast cancer cells. Int J Oncol 41: 1119-1127, 2012.

16. Vichai V and Kirtikara K: Sulforhodamine B colorimetric assay for cytotoxicity screening. Nat Protoc 1: 1112-1116, 2006.

17. $\mathrm{Lu} \mathrm{Z}$ and $\mathrm{Xu}$ S: ERK1/2 MAP kinases in cell survival and apoptosis. IUBMB Life 58: 621-631, 2006.
18. Jang K, Kim M, Seo HS and Shin I: PTEN sensitizes MDA-MB-468 cells to inhibition of MEK/Erk signaling for the blockade of cell proliferation. Oncol Rep 24: 787-793, 2010.

19. Niepel M, Hafner M, Pace EA, Chung M, Chai DH, Zhou L, Muhlich JL, Schoeberl B and Sorger PK: Analysis of growth factor signaling in genetically diverse breast cancer lines. BMC Biol 12: 20, 2014.

20. Yadav B, Taurin S, Rosengren RJ, Schumacher M, Diederich M, Somers-Edgar TJ and Larsen L: Synthesis and cytotoxic potential of heterocyclic cyclohexanone analogues of curcumin. Bioorg Med Chem 18: 6701-6707, 2010.

21. Stuart EC, Larsen L and Rosengren RJ: Potential mechanisms for the synergistic cytotoxicity elicited by 4-hydroxytamoxifen and epigallocatechin gallate in MDA-MB-231 cells. Int J Oncol 30: 1407-1412, 2007.

22. Wood CD, Thornton TM, Sabio G, Davis RA and Rincon M: Nuclear localization of p38 MAPK in response to DNA damage. Int J Biol Sci 5: 428-437, 2009.

23. Zarubin $\mathrm{T}$ and Han $\mathrm{J}$ : Activation and signaling of the p38 MAP kinase pathway. Cell Res 15: 11-18, 2005.

24. Catzavelos C, Bhattacharya N, Ung YC, Wilson JA, Roncari L, Sandhu C, Shaw P, Yeger H, Morava-Protzner I, Kapusta L, et al: Decreased levels of the cell-cycle inhibitor p27Kip1 protein: Prognostic implications in primary breast cancer. Nat Med 3: 227-230, 1997.

25. deFazio A, Chiew YE, McEvoy M, Watts CK and Sutherland RL: Antisense estrogen receptor RNA expression increases epidermal growth factor receptor gene expression in breast cancer cells. Cell Growth Differ 8: 903-911, 1997.

26. Roos W, Fabbro D, Küng W, Costa SD and Eppenberger U: Correlation between hormone dependency and the regulation of epidermal growth factor receptor by tumor promoters in human mammary carcinoma cells. Proc Natl Acad Sci USA 83: 991-995, 1986.

27. Slamon DJ, Clark GM, Wong SG, Levin WJ, Ullrich A and McGuire WL: Human breast cancer: Correlation of relapse and survival with amplification of the HER-2/neu oncogene. Science 235: 177-182, 1987.

28. Biswas DK, Shi Q, Baily S, Strickland I, Ghosh S, Pardee AB and Iglehart JD: NF-kappa B activation in human breast cancer specimens and its role in cell proliferation and apoptosis. Proc Natl Acad Sci USA 101: 10137-10142, 2004.

29. Nielsen TO, Hsu FD, Jensen K, Cheang M, Karaca G, Hu Z, Hernandez-Boussard T, Livasy C, Cowan D, Dressler L, et al: Immunohistochemical and clinical characterization of the basallike subtype of invasive breast carcinoma. Clin Cancer Res 10: 5367-5374, 2004.

30. Grandis JR and Sok JC: Signaling through the epidermal growth factor receptor during the development of malignancy. Pharmacol Ther 102: 37-46, 2004.

31. Zhuang S and Schnellmann RG: A death-promoting role for extracellular signal-regulated kinase. J Pharmacol Exp Ther 319: 991-997, 2006.

32. Bacus SS, Gudkov AV, Lowe M, Lyass L, Yung Y, Komarov AP, Keyomarsi K, Yarden Y and Seger R: Taxol-induced apoptosis depends on MAP kinase pathways (ERK and p38) and is independent of p53. Oncogene 20: 147-155, 2001.

33. Liu J, Mao W, Ding B and Liang CS: ERKs/p53 signal transduction pathway is involved in doxorubicin-induced apoptosis in H9c2 cells and cardiomyocytes. Am J Physiol Heart Circ Physiol 295: H1956-H1965, 2008.

34. She QB, Bode AM, Ma WY, Chen NY and Dong Z: Resveratrolinduced activation of p53 and apoptosis is mediated by extracellular-signal-regulated protein kinases and p38 kinase. Cancer Res 61: 1604-1610, 2001

35. Nguyen TT, Tran E, Nguyen TH, Do PT, Huynh TH and Huynh $\mathrm{H}$ : The role of activated MEK-ERK pathway in quercetininduced growth inhibition and apoptosis in A549 lung cancer cells. Carcinogenesis 25: 647-659, 2004.

36. Kolch W, Halasz M, Granovskaya M and Kholodenko BN: The dynamic control of signal transduction networks in cancer cells. Nat Rev Cancer 15: 515-527, 2015.

37. Dillon RL, White DE and Muller WJ: The phosphatidyl inositol 3-kinase signaling network: Implications for human breast cancer. Oncogene 26: 1338-1345, 2007.

38. Vivanco I and Sawyers CL: The phosphatidylinositol 3-Kinase AKT pathway in human cancer. Nat Rev Cancer 2: 489-501, 2002. 
39. Korutla L, Cheung JY, Mendelsohn J and Kumar R: Inhibition of ligand-induced activation of epidermal growth factor receptor tyrosine phosphorylation by curcumin. Carcinogenesis 16: $1741-1745,1995$.

40. Korutla L and Kumar R: Inhibitory effect of curcumin on epidermal growth factor receptor kinase activity in A431 cells. Biochim Biophys Acta 1224: 597-600, 1994.

41. Yamamoto Y, Hoshino Y, Ito T, Nariai T, Mohri T, Obana M, Hayata N, Uozumi Y, Maeda M, Fujio Y, et al: Atrogin-1 ubiquitin ligase is upregulated by doxorubicin via p38-MAP kinase in cardiac myocytes. Cardiovasc Res 79: 89-96, 2008.

42. Lee SL, Chou CC, Chuang HC, Hsu EC, Chiu PC, Kulp SK, Byrd JC and Chen CS: Functional role of mTORC2 versus integrin-linked kinase in mediating Ser473-Akt phosphorylation in PTEN-negative prostate and breast cancer cell lines. PLoS One 8: e67149, 2013.
43. O'Brien NA, Browne BC, Chow L, Wang Y, Ginther C, Arboleda J, Duffy MJ, Crown J, O'Donovan N and Slamon DJ: Activated phosphoinositide 3-kinase/AKT signaling confers resistance to trastuzumab but not lapatinib. Mol Cancer Ther 9: 1489-1502, 2010

44. Taurin S, Sandbo N, Qin Y, Browning D and Dulin NO: Phosphorylation of beta-catenin by cyclic AMP-dependent protein kinase. J Biol Chem 281: 9971-9976, 2006.

45. Lin L, Hutzen B, Ball S, Foust E, Sobo M, Deangelis S, Pandit B, Friedman L, Li C, Li PK, et al: New curcumin analogues exhibit enhanced growth-suppressive activity and inhibit AKT and signal transducer and activator of transcription 3 phosphorylation in breast and prostate cancer cells. Cancer Sci 100: 1719-1727, 2009. 